ECCOMAS

Proceedia
COMPDYN 2021

$8^{\text {th }}$ ECCOMAS Thematic Conference on Computational Methods in Structural Dynamics and Earthquake Engineering M. Papadrakakis, M. Fragiadakis (eds.) Streamed from Athens, Greece, 28 - 30 June 2021

\title{
SEISMIC RISK ASSESSMENT FOR THE ITALIAN RESIDENTIAL MASONRY BUILT STOCK AND EFFECTIVENESS OF DIFFERENT MITIGATION STRATEGIES
}

\author{
Pietro Carpanese ${ }^{1}$, Veronica Follador ${ }^{1}$, Elisa Saler ${ }^{1}$ and Francesca da Porto ${ }^{1}$ \\ ${ }^{1}$ Depart. of Geosciences - University of Padova \\ Via G. Gradenigo, 6, 35131 Padova, Italy \\ pietro.carpanese@phd.unipd.it, \{veronica.follador, elisa.saler, francesca.daporto\}@unipd.it
}

\begin{abstract}
Italy is one of the countries most subject to seismic risk, not only because of high seismicity, but also because of its significant exposure and vulnerability. These aspects can determine very high social and economic costs for the country. In order to have a good estimate of risk indicators such as economic losses, casualties and usability of buildings in the aftermath of an earthquake, some computation tools that perform damage and risk assessments can be utilized. Particularly, this work uses the Italian Risk MAps (IRMA) platform developed by Eucentre, which can produce maps of conditional damage (with a selected return period) or unconditional damage (with an observation time window) to evaluate seismic risk in Italy. IRMA allows the combination of hazard and exposure data included in the platform with vulnerability models. In this case, a vulnerability model for residential masonry is implemented within the platform to obtain the as-built risk evaluation. Moreover, a retrofitted vulnerability model is also derived, obtaining fragility curves that consider the main seismic retrofit interventions that can be performed on masonry buildings. By comparing the as-built risk evaluations with the mitigated ones, it is possible to highlight the entity of the benefit after a retrofit and compare it to its cost, at territorial scale. This analysis allows the assessment of the economic effectiveness of different seismic mitigation strategies.
\end{abstract}

Keywords: Residential Masonry Buildings, Seismic Risk Assessment, Cost-benefit analysis, Retrofit Interventions, Mitigation strategies

ISSN:2623-3347 (C) 2021 The Authors. Published by Eccomas Proceedia. Peer-review under responsibility of the organizing committee of COMPDYN 2021. doi:10.7712/120121.8661.18833 


\section{INTRODUCTION}

Seismic risk assessment is an essential task for countries with intense seismic activity, such as Italy. To carry out seismic risk analyses, it is necessary to deepen the knowledge about the various components of this risk at national scale, starting from the vulnerability assessment of the built heritage. Particular attention should be paid to historical buildings, as they usually represent the most vulnerable component of the built stock.

Not only is it important to correctly assess the seismic vulnerability of the buildings as they currently are (i.e., as-built configuration), but it is also essential to plan possible retrofit intervention strategies, in order to mitigate seismic vulnerability and reduce the losses due to seismic events. In order to do so, simulations of intervention strategies should be performed, and the mitigated vulnerability should be compared with the "as-built" one.

Seismic vulnerability is often expressed by fragility curves. In literature, several methods to derive fragility curves are available [1]: empirical methods, that calibrate fragility curves from damage data collected after seismic events $[2,3]$; mechanical methods, based on numerical or simplified models that simulate the seismic behavior of buildings $[4,5]$; and hybrid methods, characterized by features of both empirical and analytical methods [6].

In this study, the simplified mechanical method proposed by Donà et al. [7-9] was followed. Specifically, a database of 205 buildings dating from before 1919 was considered, and the seismic vulnerability for this typology was evaluated with the software Vulnus vb $4.0[10,11]$, described at \$2.1. Different vulnerability models were thus obtained, for the as built configuration and for eight retrofit solutions, considered suitable for the construction period under consideration.

As a final elaboration, the vulnerability models were used to produce seismic risk maps of Italy through the IRMA platform $[12,13]$, highlighting the differences in terms of benefit that each intervention can bring in different parts of the country.

The maps presented in this paper may reach very practical outcomes, and they can be used by risk management institutions (such as the Department of Civil Protection) as guidelines to prioritize anti-seismic actions. The results may suggest where to take action and with which strategies, in order to move towards a targeted risk mitigation at a national level.

\section{FRAGILITY CURVES FOR ITALIAN MASONRY BUILDINGS}

\subsection{Elaboration of fragility sets: tools and methodology}

In this work, the elaboration of fragility curves is carried out with Vulnus vb 4.0. Vulnus is a software developed by the University of Padova, which analyzes load-bearing masonry structures in a simplified way. It uses few geometrical, structural, and qualitative information to calculate three fragility curves representative of the overall response of buildings to horizontal actions. The three fragility curves represent the mean (White curve) and the extreme (Lower-Bounds and Upper-Bounds curves) probabilities of reaching or exceeding the acceleration value that triggers in-plane or out-of-plane mechanisms. For this reason, they are associated to a medium-severe damage state (DS2-3, intermediate between DS2 and DS3 of the EMS98 scale [14]).

The aim of the procedure presented in Donà et al. [8] is to define a fragility curve describing the behavior of an entire building macro-typology (i.e., of a category of masonry buildings belonging to the same construction period). For this reason, when applying the Vulnus procedure to a database of buildings, the curves obtained for every building have to be eventually combined. The first step of the procedure consists of averaging the single curves by municipality and by number of floors. Then, weighted means between the curves belonging to 
buildings of 1 and 2 stories and between the curves of 3, 4 and 5 stories are calculated. The weights are selected following the real distribution of the different typologies in Italy, using ISTAT 2001 census data [15]. The results are two sets of DS2-3 fragility curves representative of Low Rise (1 and 2 stories) and Mid Rise (3, 4 and 5 stories) buildings.

In order to represent seismic fragility over the five damage states (from DS1 to DS5), the fragility model of Lagomarsino and Cattari [16] is calibrated on the DS2-3 mechanical fragility curves previously obtained.

Lastly, the White, Upper- and Lower-Bounds sets are combined. The average fragility defined by the White curves is maintained (mean value of the lognormal fragility curve), whereas the dispersion parameter is adapted to the extreme probabilities range. In this way, the single fragility set derived for each building typology is more suitable to represent large-scale vulnerability.

For more detailed explanations on how the procedure is implemented, please refer to Donà et al. [8].

\subsection{Retrofit interventions for Pre-1919 buildings}

The first goal of this study is to compare different retrofit strategies and their ability to reduce seismic risk. To do so, the most adequate retrofit interventions for the building typology under investigation were studied.

As said before, this work focuses on Pre-1919 buildings. This typology of buildings is usually characterized by stone (mainly random) and solid brick masonry, timber floors and roofs, and absence of retaining elements. The consequence is usually an inadequate response to the seismic actions, making strengthening interventions necessary.

A considerable number of studies has been published on retrofit interventions for seismic vulnerability reduction. In particular, the most effective interventions for historical ordinary buildings are the following: interventions that increase strength and compactness of walls [1720], interventions that improve connections [21-23], and interventions of stiffening of floors and roofs [24-27].

For the construction period Pre-1919, four individual retrofit interventions and four combined ones were selected on the basis of field experiences in past works [28-30]. The final eight interventions are shown in Table 1.

\section{individual interventions}

\begin{tabular}{ll}
\hline MSN1 & $\begin{array}{l}1^{\text {st }} \text { stage of masonry } \\
\text { strengthening }\end{array}$ \\
\hline MSN2 & $\begin{array}{l}2^{\text {nd }} \text { stage of masonry } \\
\text { strengthening }\end{array}$ \\
\hline$T R$ & addition of tie-rods \\
\hline$F L R$ & $\begin{array}{l}\text { stiffening of floors } \\
\text { (light interventions) }\end{array}$ \\
\hline
\end{tabular}

\section{combined interventions}

$\rightarrow$\begin{tabular}{ll}
\hline$M S N 1+T R$ & $\begin{array}{l}1^{\text {st }} \text { stage of masonry strengthening + } \\
\text { addition of tie-rods }\end{array}$ \\
\hline$M S N 1+F L R$ & $\begin{array}{l}1^{\text {st }} \text { stage of masonry strengthening + } \\
\text { stiffening of floors }\end{array}$ \\
\hline$M S N 2+T R$ & $\begin{array}{l}2^{\text {nd }} \text { stage of masonry strengthening }+ \\
\text { addition of tie-rods }\end{array}$ \\
\hline$M S N 2+F L R$ & $\begin{array}{l}2^{\text {nd }} \text { stage of masonry strengthening + } \\
\text { stiffening of floors }\end{array}$ \\
\hline
\end{tabular}

Table 1: Individual and combined retrofit interventions considered significant for Pre-1919 buildings

Specifically, masonry strengthening consists in the application of light or single interventions for the $1^{\text {st }}$ stage (MSN1), while more phases of interventions or a single overall heavy intervention are associated to the $2^{\text {nd }}$ stage (MSN2). Usually, masonry interventions for Pre-1919 buildings depend on type and quality of masonry. When the masonry is inconsistent 
(i.e., random rubble and multi-leaf masonry), injections of mortar are often considered, whereas FRCM-TRM reinforced plaster (Fiber/Fabric Reinforced Cementitious Matrix/Mortar - Textile Reinforced Mortars) is taken into account in presence of stone ashlar or brick masonry.

The insertion of tie-rods (TR) is another typical intervention for masonry buildings. It improves (or even creates) the connections between structural elements (wall-to-wall and wallto-floor) and prevents the activation of out-of-plane mechanisms.

As regards to floor interventions (FLR), the most efficient solutions for historical buildings are the insertion of bracing systems or the installation of double timber planks, in order to increase the stiffness without excessively affecting the loads. In addition, connection elements anchored to the masonry and to the bearing elements of the floor must be placed to ensure the effectiveness of the intervention.

Lastly, the combined application of different interventions can improve even more the seismic response of the building.

Since Vulnus performs simplified vulnerability analyses of masonry buildings, even the interventions were implemented in a simplified way [31]. In fact, it is possible to implement some interventions directly through the options allowed by the software (insertion of tie-rods), whereas others have to be implemented indirectly, using corrective coefficients (masonry strengthening) or reproducing the effect of the intervention on the overall behavior of the building (stiffening of floors).

\subsection{Fragility curves for the as-built configuration and the intervention strategies}

The Donà et al. [8] methodology was implemented for Pre-19 buildings, firstly for the asbuilt configuration and then for each intervention presented in $\$ 2.2$. Therefore, the fragility sets related to the two building sub-typologies analyzed (Pre-1919 Low-Rise - 1, 2 stories, and Pre1919 Mid-Rise - 3, 4, 5 stories) were obtained. In Table 2 the means $(\mu)$ and standard deviations $(\beta)$ of the resulting model are reported, and in Figure 1 the values of $\mu$ for each DS are compared for Low-Rise and Mid-Rise buildings.

As expected, the results show that the interventions of masonry strengthening are overall more effective than the insertion of tie-rods or the intervention on floors. In addition, combined interventions are more effective than single ones. Moreover, it should be noticed that the reduction of vulnerability deriving from a combination of two interventions is not simply the sum of the reductions of vulnerability deriving from the two interventions performed individually.

\begin{tabular}{lccccccccccc}
\hline \multirow{2}{*}{ Interventions } & & \multicolumn{2}{c}{ DS1 } & \multicolumn{2}{c}{ DS2 } & \multicolumn{2}{c}{ DS3 } & \multicolumn{2}{c}{ DS4 } & \multicolumn{2}{c}{ DS5 } \\
& & $\mu[g]$ & $\beta[-]$ & $\mu[g]$ & $\beta[-]$ & $\mu[g]$ & $\beta[-]$ & $\mu[g]$ & $\beta[-]$ & $\mu[g]$ & $\beta[-]$ \\
\hline \multirow{2}{*}{ AS-BUILT } & $n \leq 2$ & 0.097 & 0.693 & 0.172 & 0.709 & 0.278 & 0.720 & 0.450 & 0.750 & 0.820 & 0.793 \\
& $n \geq 3$ & 0.074 & 0.743 & 0.131 & 0.768 & 0.212 & 0.777 & 0.342 & 0.776 & 0.620 & 0.809 \\
\hline \multirow{2}{*}{ FLR } & $n \leq 2$ & 0.126 & 0.735 & 0.224 & 0.757 & 0.361 & 0.747 & 0.584 & 0.751 & 1.062 & 0.756 \\
& $n \geq 3$ & 0.094 & 0.675 & 0.168 & 0.704 & 0.270 & 0.711 & 0.437 & 0.743 & 0.796 & 0.782 \\
\hline \multirow{2}{*}{ TR } & $n \leq 2$ & 0.112 & 0.746 & 0.198 & 0.774 & 0.320 & 0.761 & 0.518 & 0.775 & 0.950 & 0.807 \\
& $n \geq 3$ & 0.079 & 0.739 & 0.140 & 0.750 & 0.227 & 0.758 & 0.366 & 0.766 & 0.663 & 0.804 \\
\hline \multirow{2}{*}{ MSN1 } & $n \leq 2$ & 0.131 & 0.709 & 0.233 & 0.736 & 0.376 & 0.727 & 0.608 & 0.729 & 1.104 & 0.722 \\
& $n \geq 3$ & 0.112 & 0.758 & 0.199 & 0.788 & 0.321 & 0.774 & 0.519 & 0.788 & 0.951 & 0.814 \\
\hline \multirow{2}{*}{ MSN2 } & $n \leq 2$ & 0.153 & 0.689 & 0.271 & 0.723 & 0.438 & 0.733 & 0.709 & 0.755 & 1.290 & 0.683 \\
& $n \geq 3$ & 0.129 & 0.739 & 0.229 & 0.770 & 0.370 & 0.761 & 0.597 & 0.766 & 1.086 & 0.757 \\
\hline \multirow{2}{*}{ MSN1 + FLR } & $n \leq 2$ & 0.206 & 0.700 & 0.366 & 0.703 & 0.589 & 0.681 & 0.947 & 0.673 & 1.689 & 0.667 \\
& $n \geq 3$ & 0.153 & 0.662 & 0.271 & 0.689 & 0.437 & 0.704 & 0.707 & 0.729 & 1.286 & 0.679 \\
\hline
\end{tabular}


Pietro Carpanese, Veronica Follador, Elisa Saler and Francesca da Porto

\begin{tabular}{llllllllllll}
\hline \multirow{2}{*}{ MSN1 + TR } & $n \leq 2$ & 0.168 & 0.693 & 0.299 & 0.718 & 0.483 & 0.737 & 0.783 & 0.780 & 1.432 & 0.699 \\
& $n \geq 3$ & 0.120 & 0.738 & 0.213 & 0.762 & 0.344 & 0.748 & 0.556 & 0.753 & 1.015 & 0.776 \\
\hline \multirow{2}{*}{ MSN2 + FLR } & $n \leq 2$ & 0.263 & 0.739 & 0.467 & 0.738 & 0.755 & 0.724 & 1.217 & 0.652 & 2.161 & 0.612 \\
& $n \geq 3$ & 0.188 & 0.692 & 0.334 & 0.699 & 0.540 & 0.700 & 0.872 & 0.742 & 1.569 & 0.707 \\
\hline \multirow{2}{*}{ MSN2 + TR } & $n \leq 2$ & 0.191 & 0.732 & 0.339 & 0.738 & 0.548 & 0.729 & 0.884 & 0.760 & 1.586 & 0.708 \\
& $n \geq 3$ & 0.144 & 0.696 & 0.255 & 0.725 & 0.412 & 0.730 & 0.665 & 0.745 & 1.208 & 0.691 \\
\hline
\end{tabular}

Table 2: Means $(\mu)$ and standard deviations $(\beta)$ of the fragility model for Pre-1919 buildings in as-built condition and after the analyzed interventions (where $n$ is number of stories).

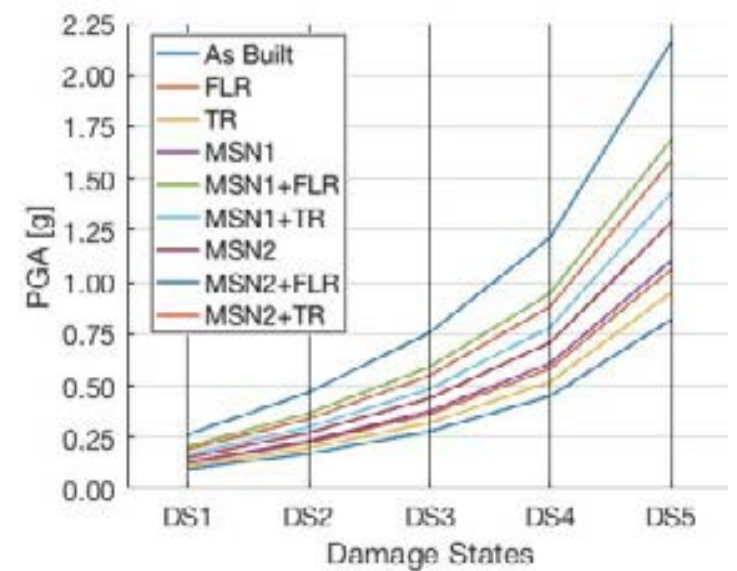

a)

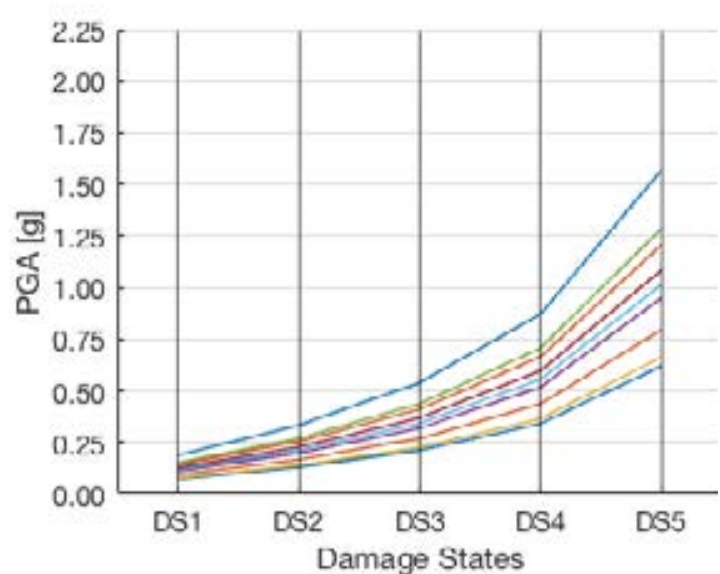

b)

Figure 1: Comparison of the means $(\mu)$ of the fragility curves for each damage state DS, for each intervention, and for: a) Low-Rise buildings $(n \leq 2)$; b) Mid-Rise buildings $(n \geq 3)$

\section{RISK MAPS}

Once the fragility curves for the as-built configuration and the intervention strategies are defined, they can be implemented in the IRMA platform. IRMA is a tool developed by Eucentre (European centre for training and research in earthquake engineering) for the Italian Department of Civil Protection: it elaborates seismic hazard, vulnerability and exposure data in Italy, in order to produce damage and risk maps. The hazard used in the platform is the MPS04 hazard model, developed by the National Institute of Geophysics and Volcanology [32]. The exposure for residential buildings derives from the Italian census data (ISTAT) and is presented in terms of number of buildings, dwellings or their total floor area at municipality level. Lastly, vulnerability can be customized and has to be given as an input by the user. In this work, the fragility models defined in $\$ 2.3$ were used.

Combining these three components, IRMA can elaborate maps of conditional damage and risk (i.e., the return period is selected), as well as maps of unconditional damage and risks (i.e., an observation time window is selected).

In this work, mainly the direct economic losses caused by earthquakes were taken into account. Table 3 shows the percentages of the repair (or replacement) cost as a function of building damage. In IRMA, the default reconstruction cost is $1350 € / \mathrm{m}^{2}$, and this value was kept throughout all the simulations. The parameters proposed in IRMA were calibrated on the actual repair costs incurred after the Italian earthquake of L'Aquila 2009 [33, 34].

The analyses carried out in the following $\S 3.1$ and $\S 3.2$ refer to an unconditional time window of 50 years, and are related to a type A soil (rocks or very rigid soils). Also, since the vulnerability models described in $\$ 2.3$ only refer to buildings belonging to Pre-1919, all the 
maps and results shown in this paper are related only to the Italian built stock from that construction period.

For further explanations about how the platform works, please refer to [13].

\begin{tabular}{|l|c|c|c|c|c|}
\cline { 2 - 5 } \multicolumn{1}{c|}{} & $D S 1$ & $D S 2$ & $D S 3$ & $D S 4$ & $D S 5$ \\
\hline$\%$ of total $\operatorname{cost}\left(1350 € / \mathrm{m}^{2}\right)$ & $2 \%$ & $10 \%$ & $30 \%$ & $60 \%$ & $100 \%$ \\
\hline
\end{tabular}

Table 3: Percentages used by the IRMA platform for computation of economic losses

\subsection{Benefit and normalized benefit}

As a first step, it is useful to compute the benefit $(B)$ expected in a time window of 50 year. $B$ is defined as the difference between economic losses for a scenario where all the buildings are in the as-built configuration $\left(E L_{a s-b u i l t}\right)$ and the economic losses in case an intervention strategy is extensively implemented at national level $\left(E L_{\text {int }}\right)$, according to equation (1):

$$
B=E L_{\text {as built }}-E L_{\text {int }}
$$

Of course, benefit is deeply influenced by exposure, as higher losses are expected in bigger tows with higher exposure. For this reason, it can be useful to visualize the results in terms of normalized benefit $(N B)$ : to obtain this variable, the benefit in each municipality is divided by its Pre-1919 exposure.

Figure 2 shows the maps with the $N B$ results for all Italian municipalities, and for each possibility of intervention presented in $\$ 2.2$ (both individual and combined interventions).
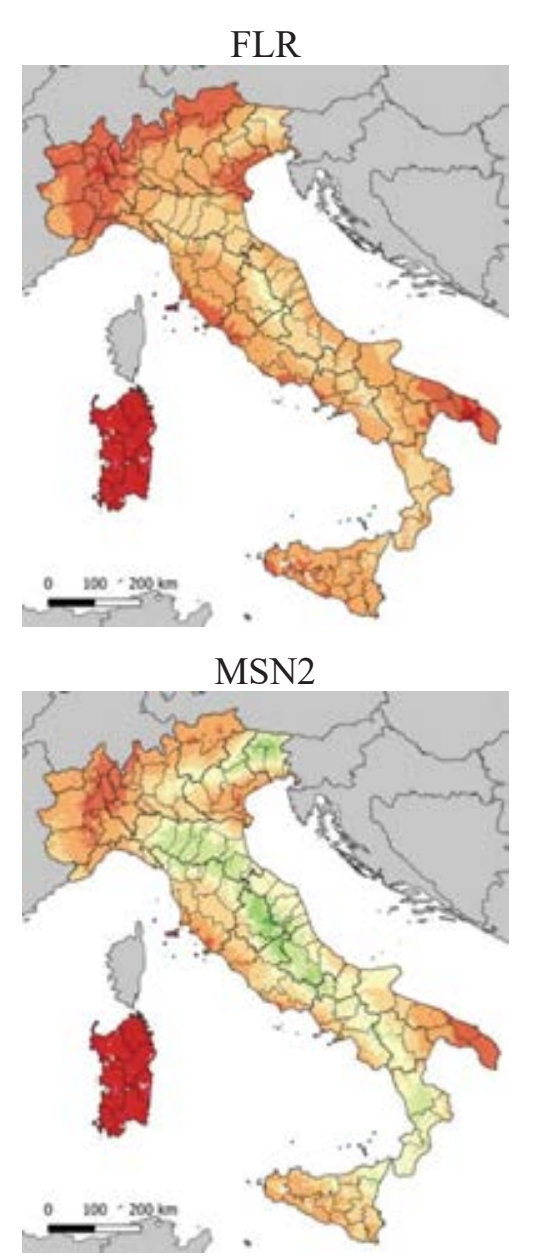
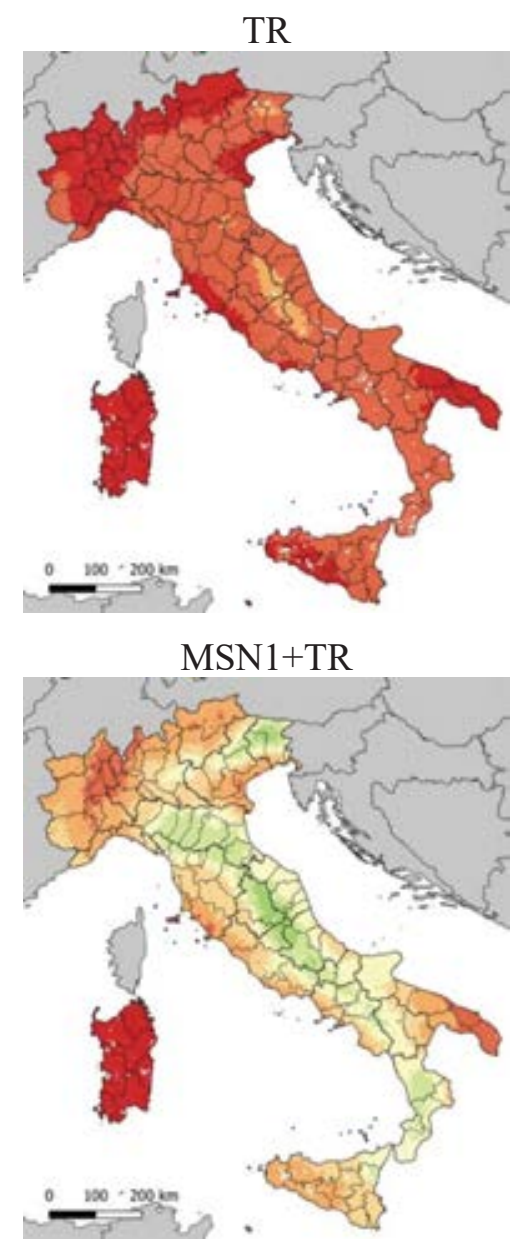

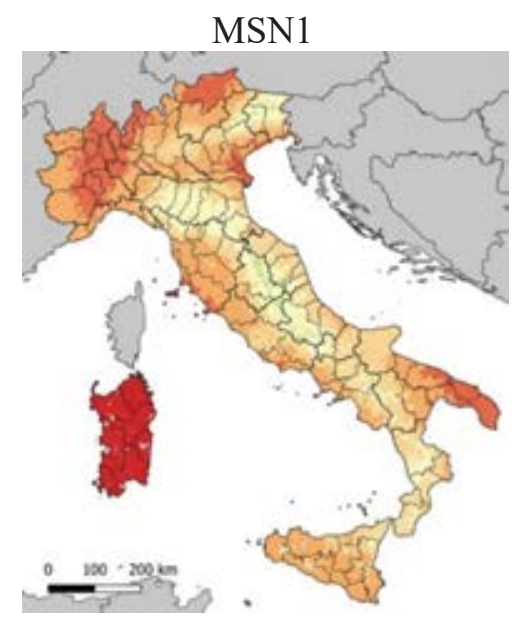

MSN1+FLR

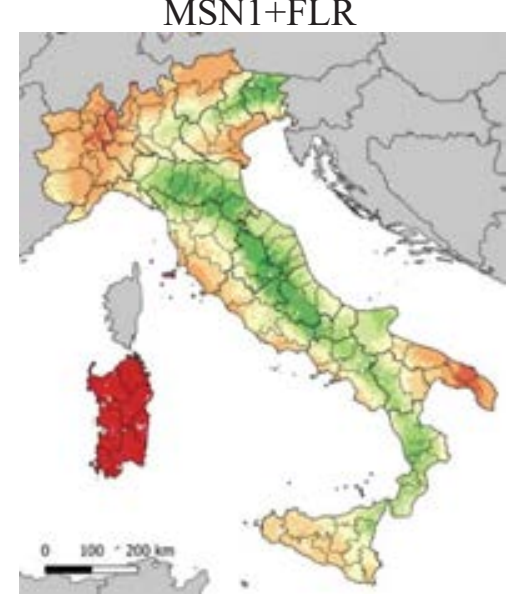



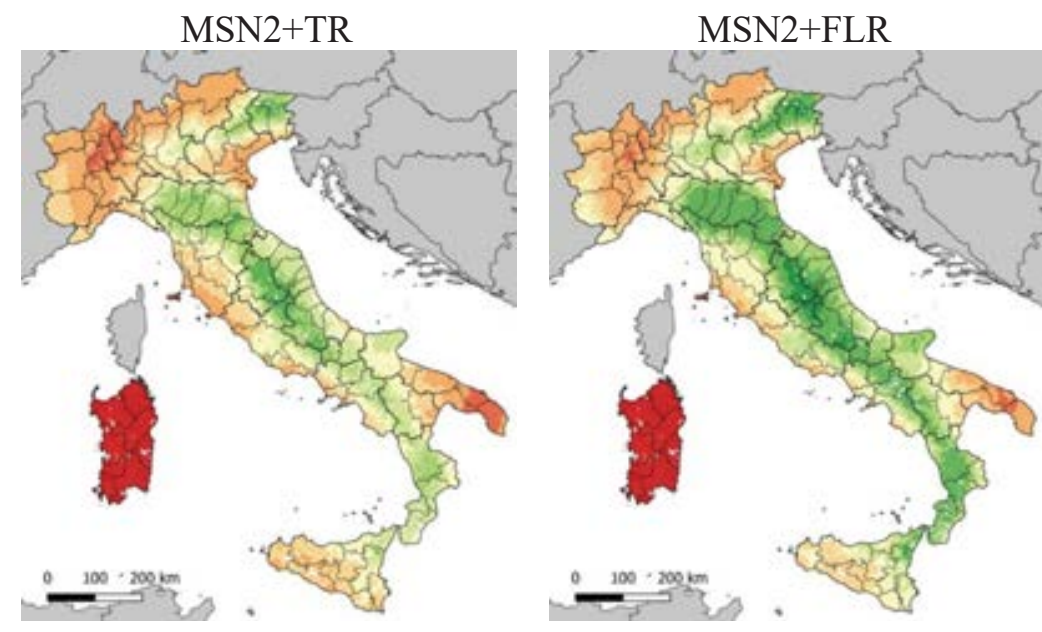

Legend $\left[€ / \mathrm{m}^{2}\right]$

Figure 2: Normalized benefit $(N B)$ maps of Italy for the retrofit interventions considered

It should be notice how some combined strategies lead to the same overall results as some individual ones (for example, the map for MSN1+TR is very similar to the one for MSN2). This consideration could be significant when planning mitigation actions at territorial scale.

\subsection{Cost-benefit analysis}

In order to assess the real economic effectiveness of the interventions analyzed, the benefit $B$ has to be compared with the cost $C$ of these interventions. In particular, $B$ is divided by $C$, thus obtaining an index $I$.

When $I$ is equal to or greater than 1 , this means that the benefit exceeds the cost, making the initial investment economically reasonable. The lower the value of $I$, the less economically justified the intervention will be. Table 4 shows the costs per square meter that were estimated for each intervention [35].

\begin{tabular}{lr}
\hline INTERVENTIONS & COST $\left[\boldsymbol{\epsilon} / \mathbf{m}^{2}\right]$ \\
\hline $\boldsymbol{F L R}$ & 185 \\
\hline $\boldsymbol{T R}$ & \\
$\quad$ Low-Rise buildings (1-2 stories) & 110 \\
$\quad$ Mid-Rise buildings (3-4-5 stories) & 45 \\
\hline MSN1 & 140 \\
\hline MSN1+FLR & 330 \\
\hline MSN1+ TR & \\
$\quad$ Low-Rise buildings (1-2 stories) & 250 \\
Mid-Rise buildings (3-4-5 stories) & 190 \\
\hline MSN2 & 210 \\
\hline MSN2 + FLR & 395 \\
\hline MSN2 + TR & 320 \\
$\quad$ Low-Rise buildings (1-2 stories) & 255 \\
$\quad$ Mid-Rise buildings (3-4-5 stories) & \\
\hline
\end{tabular}

Table 4: Costs in $€ / \mathrm{m}^{2}$ for each intervention considered

In this work, the aim of the cost-benefit analysis is to identify the most convenient retrofit strategy in different Italian locations. 
In this procedure, each Italian municipality will have eight indices $I$ (one for each intervention proposed). The group of eight indices $I$ for each municipality will match one of the following cases:

1. if some or all of them are greater than 0.5 (i.e., more than $50 \%$ of the initial cost will be totally recovered in 50 years): among the ones that meet this condition, the most performing intervention is chosen (i.e., the one that gives the greatest benefit $B$ );

2. if some or all of them are lower than 0.5 but greater than 0.3 (i.e., between 30 and $50 \%$ of the initial cost will be totally recovered in 50 years): among the ones that meet this condition, the cheapest intervention is chosen (i.e., the ones with the lowest $\operatorname{cost} C$ );

3. if all the indices are less than 0.3 (i.e., less than $30 \%$ of the initial cost will be totally recovered in 50 years): no intervention strategy is considered effective enough.

As can be noticed, the value $I=0.5$ sets a decision boundary: in case interventions have $I>0.5$, their performance is taken into account, while when $K<0.5$ their affordability will be considered first. This choice can be explained remembering that the values here calculated only take into consideration the direct losses; if all the other costs were be included, the values of $I$ would approximately double [36].

Figure 3 shows the results of this calculation for each Italian municipality.

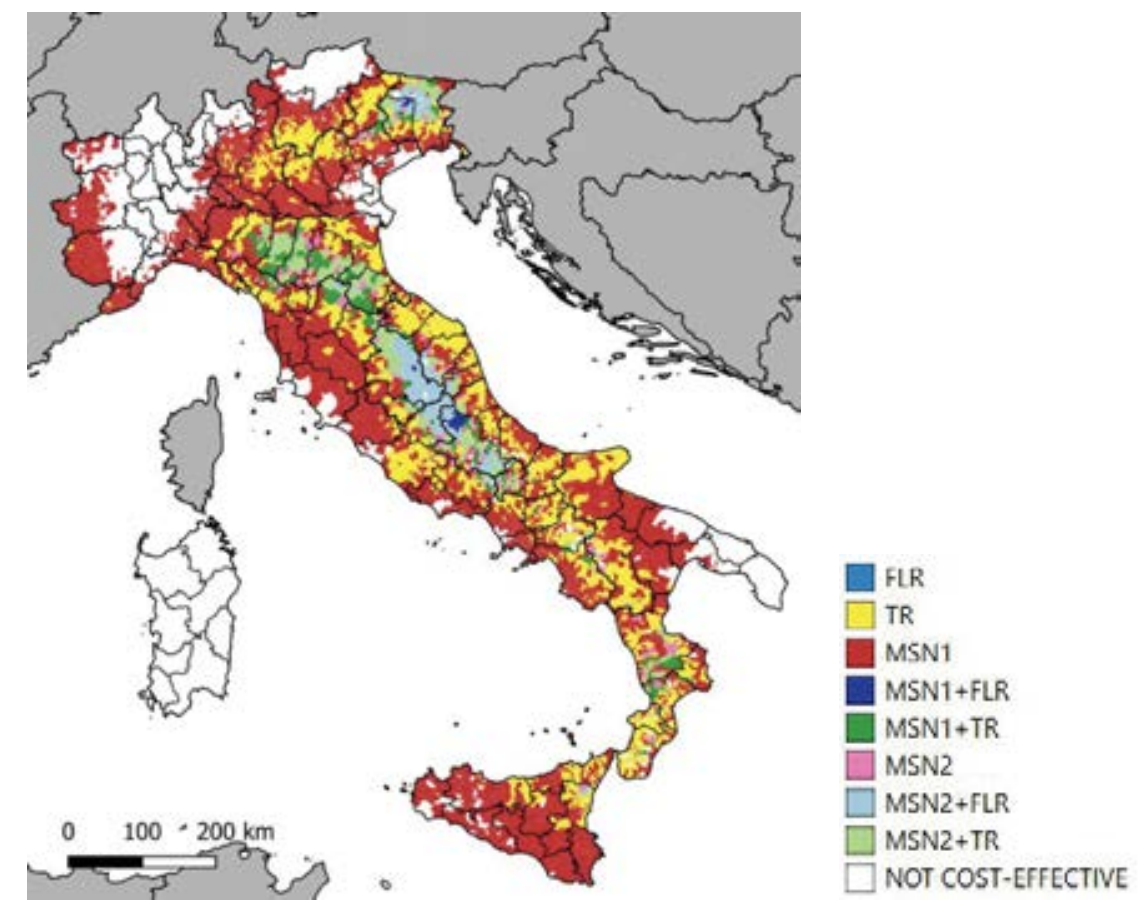

Figure 3: Cost-effectiveness map, derived from the cost-benefit analysis

Firstly, the map shows how more invasive interventions (as, for example, combined ones) are economically effective in areas with a higher seismic hazard (Central Italy, North-East Italy). The choice of which specific intervention should be implemented often derives from the exposure in the specific analyzed municipality. In zones with a medium-low seismic hazard, usually individual interventions are considered sufficient. Where seismic hazard is very low, no retrofit intervention seems economically effective in a time window of 50 years. 


\subsection{Recovery time of the initial cost of interventions}

Other than the choice of the most effective intervention strategy, it is interesting to evaluate in how many years the cost of interventions can be recovered, i.e., in what year $t$, from the date on which the intervention was implemented, the benefit $B$ fully recovers the initial cost $C$. In order to do so, the benefit is initially calculated for a time window of 1 year, and then updated year by year to obtain a gross present value $(G P V)$, according to equation (2):

$$
\operatorname{GPV}(t)=B_{1 \text { year }} \cdot \sum_{t=1}^{T} \frac{(1+f)^{t}}{(1+r)^{t}}
$$

where $f$ is the inflation rate, and $r$ is the discount rate. For this work, $f=0.01$ and $r=0.02$ were assumed [37].

By updating the benefit $B$, there will be a year $t$ when the benefit $B$ reaches or overcomes the initial cost $C$. This represents indeed the recovery time of an intervention. The maps in Figure 4 show the recovery time of the interventions considered.

The single light intervention on masonry (MSN1) results to have the shortest recovery time in large part of the national area, due to its well-balanced benefits and costs of intervention. Other types of light retrofit strategies instead, such as tie-rods, are surely less expensive, but the provided benefit appears to be insufficient to effectively recover the cost (albeit limited) of intervention.
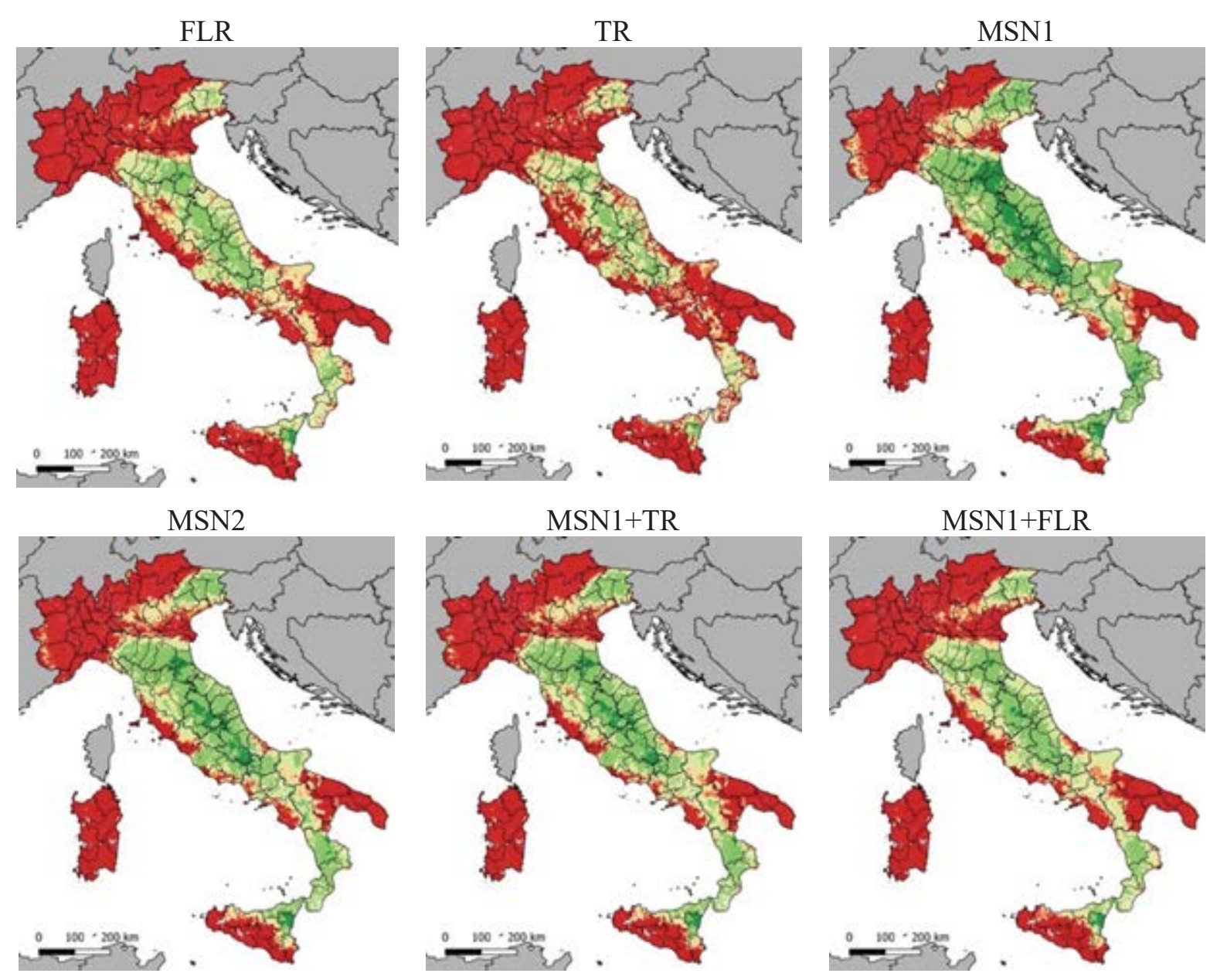

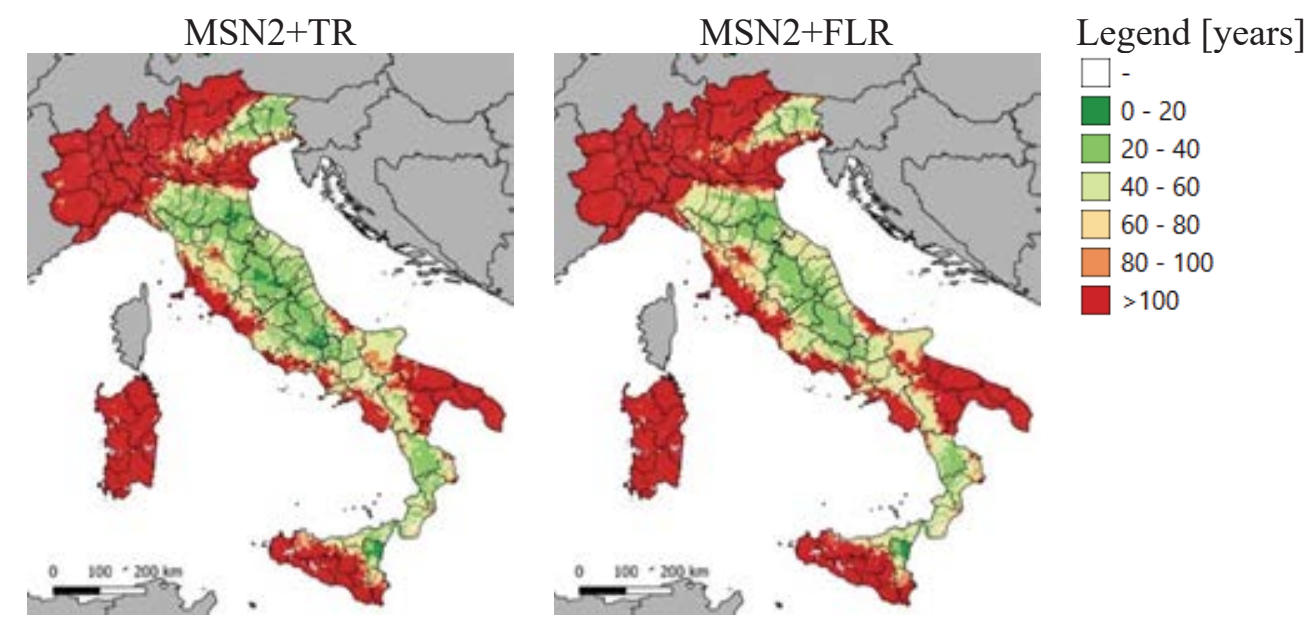

Figure 4: Recovery time of the initial cost of each intervention strategy

\section{CONCLUSIONS}

- A simplified mechanical method was used to create fragility curves for Pre-1919 buildings, both in their as-built configuration and with simulated retrofit interventions.

- Some applications of these fragility curves have been shown in terms of risk maps. Mitigated risk maps were created, showing the difference between the as-built configuration and the retrofitted one. Through a cost-benefit analysis, the costeffectiveness of the retrofit interventions was evaluated. For each Italian municipality, a specific intervention strategy was considered more convenient, depending on seismic hazard and exposure. A calculation for estimating the recovery time of the interventions was also proposed.

- The maps presented in this paper can be essential tools for authorities and decision-makers, when planning risk mitigation strategies at territorial or even national scale.

- The results provided in this paper only take into account the masonry historical built stock in Italy (i.e., built before 1919). The final aim of this work is to obtain a vulnerability model (both as-built and retrofitted) also for more recent building typologies. In this way, the seismic risk analyses and the mitigation assessments will consider the whole exposure in Italy. Then, a natural progression of the present work is to carry out more detailed risk analyses in terms of economic losses (including the estimation of indirect losses), which would lead to the selection of intervention strategies in a more sophisticated way. In addition, possible casualties (in terms of injuries and victims) will have to be taken into account in order to make these estimations more valid.

\section{ACKNOWLEDGEMENTS}

Special thanks are due to the Italian Department of Civil Protection (DPC), which funded this study in the framework of the ReLUIS-DPC Project 2019-2021 - Work Package 4: MARS (MAps of Risk and Scenarios of seismic damage)-Task 6: Preventive strategies: comparative analysis in terms of risk at national scale (Strategie preventive: analisi comparata in termini di rischio a scala nazionale).

We would also like to thank Eucentre (European centre for training and research in earthquake engineering) for creating the IRMA platform and giving access to our research unit. 


\section{REFERENCES}

[1] G.M. Calvi, R. Pinho, G. Magenes, J.J. Bommer, L.F. Restrepo-Veléz, H. Crowley, The development of seismic vulnerability assessment methodologies for variable geographical scales over the past 30 years. ISET Journal of Earthquake Technology, 43, 75-104, 2006.

[2] T. Rossetto, I. Ioannou, D.N. Grant, Existing empirical fragility and vulnerability functions: Compendium and guide for selection. GEM Technical Report 2013-X, GEM Foundation, Pavia, Italy, 2013.

[3] A. Rosti, M. Rota, A. Penna, Empirical fragility curves for Italian URM buildings. Bulletin of Earthquake Engineering, 2020.

[4] D. D’Ayala, A. Meslem, D. Vamvatsikos, K. Porter, T. Rossetto, V. Silva, Guidelines for analytical vulnerability assessment of low/mid-rise buildings, Vulnerability Global Component Project. GEM Technical Report, 2015.

[5] B. Borzi, M. Faravelli, A. Di Meo, Application of the SP-BELA methodology to RC residential buildings in Italy to produce seismic risk maps for the national risk assessment. Bulletin of Earthquake Engineering, 2020.

[6] AJ. Kappos, G. Panagopoulos, C. Panagiotopoulos, G. Penelis, A hybrid method for the vulnerability assessment of RC and URM buildings. Bulletin of Earthquake Engineering, 4, 391-413, 2006.

[7] M. Donà, P. Carpanese, V. Follador, F. da Porto, Derivation of mechanical fragility curves for macro-typologies of Italian masonry buildings. M. Papadrakakis, M. Fragiadakis eds. 7th ECCOMAS Thematic Conference on Computational Methods in Structural Dynamics and Earthquake Engineering (COMPDYN 2019), Crete, Greece, June 24-26, 2019.

[8] M. Donà, P. Carpanese, V. Follador, L. Sbrogiò, F. da Porto, Mechanics-based fragility curves for Italian residential URM buildings. Bulletin of Earthquake Engineering, 2020.

[9] M. Vettore, M. Donà, P. Carpanese, V. Follador, F. da Porto, M.R. Valluzzi, A Multilevel Procedure at Urban Scale to Assess the Vulnerability and the Exposure of Residential Masonry Buildings: The Case Study of Pordenone, Northeast Italy. Heritage, 3(4), 1433$1468,2020$.

[10] A. Bernardini, M. Gori, C. Modena, Application of coupled analytical models and experimental kowledge to seismic vulnerability analyses of masonry buildings, A. Koridze ed. Earthquake damage evaluation and vulnerability analysis of Building structures, INEEC, Omega Scientific, Ozon, 161-180, 1990.

[11] MR. Valluzzi, Manuale d'uso del programma Vulnus 4.0, programma originario di A. Bernardini, R. Gori, C. Modena, versione Vb a cura di M.R. Valluzzi, contributi di G. Benincà, E. Barbetta, M. Munari, 2009. (in Italian)

[12] F. da Porto, M. Donà, A. Rosti, M. Rota, S. Lagomarsino, S. Cattari, B. Borzi, M. Onida, D. De Gregorio, F.L. Perelli, C. Del Gaudio, P. Ricci, E. Speranza. Comparative analysis of the fragility curves for Italian residential masonry and RC buildings. Bulletin of Earthquake Engineering, Special Issue: Seismic Risk Assessment in Italy, 2021. 
[13] B. Borzi, M. Onida, M. Faravelli, D. Polli, M. Pagano, D. Quaroni, A. Cantoni, E. Speranza, C. Moroni. IRMA platform for the calculation of damages and risks of Italian residential buildings. Bulletin of Earthquake Engineering, 2020.

[14] G. Grünthal, European Macroseismic Scale. Chaiers du Centre Européen de Géodynamique et de Séismologie, vol. 15. Luxembourg, 1998.

[15] Italian National Institute of Statistics (ISTAT 2001) Website and data warehouse, 2001. https://www.istat.it/it/censimenti-permanenti/censimenti-precedenti/popolazione-eabitazioni/popolazione-2001

[16] S. Lagomarsino, S. Cattari, Fragility functions of masonry buildings, (Chapter 5), K. Pitilakis, H. Crowley, A.M. Kaynia eds. SYNER-G: Typology Definition and Fragility Functions for Physical Elements at Seismic Risk, Vol. 27, 111- 156, Springer 2014.

[17] MR. Valluzzi, F. da Porto, C. Modena, Behavior and modeling of strengthened three-leaf stone masonry walls. Materials and Structures, 37, 184-192, 2004.

[18] N. Mazzon, MR. Valluzzi, T. Aoki, E. Garbin, G. De Canio, N. Ranieri, C. Modena, Shaking table tests on two multi-leaf stone masonry buildings. $11^{\text {th }}$ Canadian Masonry Symposium, Toronto, Canada, May 31-June 3, 2009.

[19] B. Silva, M. Dalla Benetta, F. da Porto, MR. Valluzzi, Compression and Sonic Tests to Assess Effectiveness of Grout Injection on Three-Leaf Stone Masonry Walls. International Journal of Architectural Heritage, 8, 408-435, 2014.

[20] M. Giaretton, D. Dizhur, E. Garbin, J. Ingham, F. da Porto, In-plane strengthening of clay brick and block masonry walls using textile-reinforced mortar. Journal of Composites for Construction, 22(5), 2018.

[21] C. Modena, F. Casarin, F. da Porto, E. Garbin, N. Mazzon, M. Munari, M. Panizza, MR. Valluzzi, Structural interventions on historical masonry buildings: review of Eurocode 8 provisions in the light of the Italian experience. E. Cosenza ed. Eurocode 8 Perspectives from the Italian Standpoint, 225 - 236, Napoli, Doppiavoce, 2009.

[22] C. Modena, MR. Valluzzi, F. da Porto, F. Casarin, Structural Aspects of The Conservation of Historic Masonry Constructions in Seismic Areas: Remedial Measures and Emergency Actions. International Journal of Architectural Heritage, 5, 539-558, 2011.

[23] F. da Porto, MR. Valluzzi, M. Munari, C. Modena, A. Arêde, AA. Costa, Strengthening of Stone and Brick Masonry Buildings. AA. Costa, A. Arêde, H. Varum (eds) Strengthening and Retrofitting of Existing Structures. Building Pathology and Rehabilitation, vol 9. Springer, Singapore, 2018.

[24] MR. Valluzzi, E. Garbin, M. Dalla Benedetta, C. Modena, In-plane strengthening of timber floors for the seismic improvement of masonry buildings. World Conference on Timber Engineering (WCTE), Curran Associates, Red Hook, NY, 2010.

[25] MR. Valluzzi, E. Garbin, M. Dalla Benedetta, C. Modena, Experimental assessment and modelling of in-plane behaviour of timber floors. VI Int. Conf. on Structural Analysis of Historical Constructions (SAHC08), Bath, United Kingdom, July 2nd-4 ${ }^{\text {th }}, 2008$.

[26] D. Dizhur, M. Giaretton, J. Ingham, URM wall-to-diaphragm and timber joist connection testing. 10th International Masonry Conference - IMC, Milan, Italy, July 2018. 
[27] M. Giaretton, I. Giongo, D. Dizhur, Field testing of unreinforced masonry wall-todiaphragm connection via through-bolt plate anchors and timber blocking. Masonry International, 32, 63-71, 2019.

[28] Y. Saretta, L. Sbrogiò, M.R. Valluzzi, Seismic response of masonry buildings in historic centres struck by the 2016 Central Italy earthquake. Calibration of a vulnerability model for strengthened conditions, Constr. Build. Mater. (in print).

[29] M. Vettore, Y. Saretta, L. Sbrogiò, M.R. Valluzzi, A New Methodology for the Survey and Evaluation of Seismic Damage and Vulnerability Entailed by Structural Interventions on Masonry Buildings: Validation on the Town of Castelsantangelo sul Nera (MC), Italy. Int. J. Archit. Herit., 1-26, 2020.

[30] M.R. Valluzzi, L. Sbrogiò, Y. Saretta, H. Wenliuhan, Seismic response of masonry buildings in historical centres struck by the 2016 Central Italy earthquake. Impact of building fea-tures on damage evaluation. Int. J. Archit. Herit. (in print).

[31] V. Follador, M. Donà, P. Carpanese, F. da Porto, Fragility curves for Italian residential masonry buildings with retrofit interventions. 8th ECCOMAS Thematic Conference on Computational Methods in Structural Dynamics and Earthquake Engineering (COMPDYN 2021), Athens, Greece, June 27-30, 2021. (under review)

[32] M. Stucchi, C. Meletti, V. Montaldo, Seismic hazard assessment (2003-2009) for the Italian building code. Bulletin of the Seismological Society of America, 101(4), 18851911, 2011.

[33] M. Di Ludovico, A. Prota, C. Moroni, Reconstruction process of damaged residential buildings outside historical centres after the L'Aquila earthquake: part I - "light damage" reconstruction. Bulletin of Earthquake Engineering, 15, 667-692, 2017.

[34] M. Di Ludovico, A. Prota, C. Moroni, Reconstruction process of damaged residential buildings outside historical centres after the L'Aquila earthquake: part II - "heavy damage" reconstruction. Bulletin of Earthquake Engineering, 15, 693-729, 2017.

[35] DEI, Prezzi informativi dell'edilizia, DEI - Tipografia del genio civile, 2019. (in italian)

[36] M. Dolce, D. Di Bucci, Comparing recent Italian earthquakes. Bulletin of Earthquake Engineering, 15(2), 497-533, 2017.

[37] M. Donà, L. Bizzaro, F. Carturan, F. da Porto, Effects of business recovery strategies on seismic risk and cost-effectiveness of structural retrofitting for business enterprises. Earthquake Spectra, 35(4), 1795-1819, 2019. 